\title{
Differential Susceptibility to Cadmium-Induced Liver and Kidney Injury in Wild and Laboratory-Bred Bank Voles Myodes glareolus
}

\author{
Aneta Salińska • Tadeusz Włostowski • \\ Ewa Oleńska
}

Received: 19 December 2012/ Accepted: 3 March 2013/Published online: 6 April 2013

(c) The Author(s) 2013. This article is published with open access at Springerlink.com

\begin{abstract}
The objective of the study was to compare the sensitivity of wild and laboratory-bred bank voles to cadmium (Cd)-induced histopathological changes in the liver and kidneys. For 4 weeks, the male bank voles—both wild and laboratory-bred-were provided with diet containing Cd in quantities $<0.1$ (control), 30, and $60 \mu \mathrm{g} / \mathrm{g}$ dry weight. At the end of exposure period, histopathology and analyses of Cd, metallothionein (MT), glutathione (GSH), zinc ( $\mathrm{Zn}$ ), copper $(\mathrm{Cu})$, iron $(\mathrm{Fe})$, and lipid peroxidation-all considered to be critical factors during the development of $\mathrm{Cd}$ toxicity in the liver and kidneys-were carried out. Histopathological changes (focal hepatocyte swelling, vacuolation and inflammation [leukocyte infiltration] in the liver, and focal proximal tubule degeneration [including epithelial cell swelling] in the kidneys) occurred only in the wild bank voles fed a diet containing $60 \mu \mathrm{g} \mathrm{Cd} / \mathrm{g}$. There were no differences in concentrations of $\mathrm{Cd}, \mathrm{MT}, \mathrm{GSH}, \mathrm{Zn}$, and $\mathrm{Cu}$ in liver and kidney between the respective groups of wild and laboratory-bred animals. However, a decrease of hepatic $\mathrm{Fe}$ and lipid peroxidation was observed in the wild voles exhibiting histopathological changes. These data indicate the following: (1) wild bank voles are more susceptible to Cd-induced liver and kidney injury than those bred and raised in the laboratory; (2) the difference in sensitivity may be associated with a distinct decrease of hepatic $\mathrm{Fe}$ in response to $\mathrm{Cd}$ exposure between the two groups of bank voles; and (3) dietary $\mathrm{Cd}$ may produce histopathological changes indirectly through decreasing the hepatic $\mathrm{Fe}$ and $\mathrm{Fe}$-dependent oxidative processes. These results also suggest that histopathology in the liver and
\end{abstract}

\footnotetext{
A. Salińska $\cdot$ T. Włostowski $(\bowtie) \cdot$ E. Oleńska

Institute of Biology, University of Białystok, Świerkowa 20B, 15-950 Białystok, Poland

e-mail: twlostow@uwb.edu.pl
}

kidney of wild bank voles living in a contaminated environment may occur at relatively low levels of tissue $\mathrm{Cd}$.

Cadmium $(\mathrm{Cd})$ is a toxic metal widely distributed in the environment as a result of industrial and agricultural practices (Liu 2003; Satarug et al. 2003; Thévenod 2009). The source of Cd intake is mostly food, and most of the metal that is absorbed after oral exposure mainly accumulates in the liver and kidney (Lehman and Klaassen 1986), where it induces production of metallothionein (MT), a low molecular-weight protein that binds $\mathrm{Cd}$ with high affinity (Klaassen et al. 2009). The protein forming a complex with $\mathrm{Cd}$ decreases its free concentration within the cell, thus decreasing the toxic potential of $\mathrm{Cd}$. When the binding capacity of MT becomes saturated, the increased level of unbound $\mathrm{Cd}$ ions initiates processes that can lead to liver and kidney injury (Goyer et al. 1989; Włostowski et al. 2004). In liver, chronic Cd exposure produces nonspecific inflammation, hepatocyte swelling, and mild necrosis (Habeebu et al. 2000; Włostowski et al. 2000, 2004). The following processes may be involved in the development of hepatotoxicity: (1) Cd activation of Kupffer cells that induce inflammation (Kuester et al. 2002); (2) Cd injury of hepatic endothelial cells that obstruct the capillary lumen, thereby producing local hypoxia (Liu et al. 1992; Kuester et al. 2002); and (3) Cd induction of hepatic iron (Fe) depression, which may cause disturbances in Fe-dependent oxidative processes, e.g., adenosine triphosphate (ATP) synthesis (Włostowski et al. 2000, 2003). It is thought that injured hepatocytes release a Cd-MT complex into the blood, which is then filtered in the kidneys through glomeruli and reabsorbed by proximal tubule epithelial cells, which are the target for extracellular Cd-MT (Sabolić et al. 2010). After degradation of the complex in these cells, $\mathrm{Cd}$ ions induce 
oxidative stress that causes, among others, mitochondrial swelling and loss of cristae as well as an inhibition of $\mathrm{Na}^{+}-$ $\mathrm{K}^{+}$-ATPase (Thévenod and Friedmann 1999; Wang et al. 2010). These events eventually lead to loss of ionic control and cellular injury.

During chronic exposure, $\mathrm{Cd}$-induced toxicity in liver and kidney is dependent on hepatic and renal Cd concentrations (Groten et al. 1994; Liu et al. 1998; Włostowski et al. 2004). Notably, various wild animals inhabiting polluted sites exhibit histopathological changes in liver or kidney at $\mathrm{Cd}$ concentrations that are several-fold lower compared with those in animals exposed to $\mathrm{Cd}$ under laboratory conditions (Beiglböck et al. 2002; Damek-Poprawa and Sawicka-Kapusta 2004; Sanchez-Chardi et al. 2009; Włostowski et al. 2010). For example, in a small rodent, the bank vole from an industrialized area, hepatic and renal injury occurs at tissue $\mathrm{Cd}$ levels $<10 \mu \mathrm{g} / \mathrm{g}$ wet weight (Damek-Poprawa and Sawicka-Kapusta 2004), whereas in the laboratory-bred bank voles exposed to $\mathrm{Cd}$, histopathology in the liver and kidney is evident only when the concentration is $>40 \mu \mathrm{g} / \mathrm{g}$ wet weight (Włostowski et al. 2004). However, the exact reason for this difference is not known; to date, no direct comparison of the sensitivity of wild with that of laboratory-bred bank voles and other species exposed to $\mathrm{Cd}$ has been reported. Therefore, the objective of the present study was to compare the susceptibility of wild bank voles living in a relatively uncontaminated area with that of laboratory-bred voles to liver and kidney injury induced by dietary $\mathrm{Cd}$. Toxicity was evaluated by assessing liver and kidney histopathology. Analyses of MT, glutathione (GSH), and zinc (Zn), which are known to decrease $\mathrm{Cd}$ toxicity (Chan and Cherian 1992; Jacquillet et al. 2006; Jihen et al. 2008), as well as $\mathrm{Cd}, \mathrm{Fe}$, copper $(\mathrm{Cu})$ and lipid peroxidation, which are responsible for the progression of toxicity (Thévenod and Friedmann 1999; Liu et al. 2009; Whittaker et al. 2011), were carried out to determine whether the different susceptibility (if any) is associated with MT induction, GSH content, trace-element concentrations, or oxidative stress.

\section{Materials and Methods}

\section{Animals and Experimental Design}

All experimental procedures were approved by the Local Ethical Committee (Medical University of Białystok) and were compatible with the standards of the Polish Law on Experimenting on Animals, which implements the European Communities Council Directive (86/609/EEC). Wild male bank voles (weight 13.5-15.0 g, age 1.5-2.0 months) were caught in September 2011 in live traps in the Knyszyn Old Forest (northeastern Poland, the least contaminated region of
Poland). The group of laboratory-bred male bank voles (weight 13-14.5 g, age 1.5 months) were the F2 offspring of the wild-caught stock (Knyszyn Old Forest). The wild and laboratory-bred bank voles were randomly divided into three subgroups ( $n=6$ each) according to dietary Cd exposure: (1) control, (2) Cd-30 $\mu \mathrm{g} / \mathrm{g}$, and (3) Cd-60 $\mu \mathrm{g} / \mathrm{g}$ dry weight. The animals were housed individually for 4 weeks in stainlesssteel cages $(44 \times 27 \times 20 \mathrm{~cm})$ (lined with peat as absorptive material) at $18-20{ }^{\circ} \mathrm{C}$ under a $12: 12$ hour light-to-dark cycle and at 50-70 \% relative humidity. They received ad libitum distilled water and control or Cd-containing whole wheat grains, which appeared to be an adequate-quality food for these rodents (Włostowski et al. 2004). In addition, an identical quantity of apple was offered to all voles ( $3 \mathrm{~g} / \mathrm{vole} / \mathrm{wk}$ ), who ate it completely. Food intake was monitored throughout the experiment. Before the experiment, the grains were contaminated with $\mathrm{Cd}$ (soaked in $\mathrm{CdCl}_{2}$ solution). Atomic absorption spectrophotometry (AAS) analysis of the grains revealed that actual levels of $\mathrm{Cd}$ were between 28 and $33 \mu \mathrm{g} / \mathrm{g}$ (Cd-30) and 58 and $63 \mu \mathrm{g} / \mathrm{g}(\mathrm{Cd}-60)$. Control grains contained $<0.1 \mu \mathrm{g} \mathrm{Cd} / \mathrm{g}$. The concentrations of $\mathrm{Zn}, \mathrm{Cu}$, and $\mathrm{Fe}$ in the grains were 22-26, 4-6, and 80-100 $\mu \mathrm{g} / \mathrm{g}$ dry weight, respectively. The chosen concentrations of dietary $\mathrm{Cd}$ were similar or twofold greater than those found in a heavily contaminated environment (Liu 2003).

At the end of the 4 week exposure period, the bank voles were weighed, killed by decapitation, and the liver and kidneys removed, rinsed in cold saline, and blotted dry on absorbent paper. Blood was also taken to determine hemoglobin and hematocrit by using standard methods (spectrophotometrically as cyanmethemoglobin at $540 \mathrm{~nm}$ and hematocrit centrifuge, respectively). A portion of fresh liver $(0.25 \mathrm{~g})$ and one kidney were transferred to $1.0 \mathrm{~mL}$ of chilled $0.25 \mathrm{M}$ sucrose and homogenized with a Teflon pestle in a glass homogenizer. Aliquots $(0.5$ and $0.1 \mathrm{~mL})$ of the homogenate were taken for determination of metal concentrations and lipid peroxidation, respectively. The remaining homogenate was centrifuged at $20,000 \times g$ for $20 \mathrm{~min}$ at $4{ }^{\circ} \mathrm{C}$ and the resulting supernatant removed for MT and GSH assays.

\section{Histological Examination}

A portion of liver and one kidney were fixed in $4 \%$ formaldehyde, dehydrated in ethanol and xylene, embedded in paraffin, cut into $5 \mu \mathrm{m}$ sections, and stained with hematoxylin and eosin for microscopic examination.

\section{Metal Determination}

Metal determinations were performed as described recently in Salińska et al. (2012). The homogenate $(0.5 \mathrm{~mL})$ was placed in a glass tube with $2.0 \mathrm{~mL}$ of concentrated nitric 
acid (Sigma-Aldrich). After $20 \mathrm{~h}$ of sample digestion at room temperature, $72 \%$ perchloric acid $(0.5 \mathrm{~mL}$ ) (SigmaAldrich) was added and the mixture heated at $100{ }^{\circ} \mathrm{C}$ for $3 \mathrm{~h}$. Finally, the temperature was increased to $150^{\circ}-180{ }^{\circ} \mathrm{C}$ and digestion continued for another $2 \mathrm{~h}$. Deionized water was added to the residue $(0.1 \mathrm{~mL})$ after digestion to a volume of $3.0 \mathrm{~mL}$ (first solution). A portion of the first solution $(200 \mu \mathrm{L})$ was evaporated to dryness in a quartz crucible at $130{ }^{\circ} \mathrm{C}$, and the residue was redissolved in an appropriate amount of deionized water (second solution). Cd analyses of these solutions were carried out by electrothermal AAS using a Solaar M6 instrument with a Zeeman correction. The concentrations of $\mathrm{Zn}, \mathrm{Cu}$, and $\mathrm{Fe}$ in the first solution were determined by AAS in an air-acetylene flame with deuterium correction. Quality-assurance procedures included the analysis of reagent blanks and appropriate standard reference material (National Institute of Standards and Technology bovine liver $1577 \mathrm{~b}$ ). The recoveries of $\mathrm{Cd}, \mathrm{Zn}, \mathrm{Cu}$, and $\mathrm{Fe}$ were 91-93, 90-95, 89-95, and 95-101\%, respectively.

\section{MT Determination}

MT in liver and kidney was determined by Cd-saturation method (Włostowski et al. 2004). Briefly, a $0.1 \mathrm{~mL}$ sample was incubated in a $1.5 \mathrm{~mL}$ vial for $10 \mathrm{~min}$ at room temperature with $1.0 \mathrm{~mL}$ Tris- $\mathrm{HCl}$ buffer $(0.03 \mathrm{M}, \mathrm{pH} 7.8)$ containing $1.0 \mu \mathrm{g} \mathrm{Cd} / \mathrm{mL}$. To remove non-MT-bound $\mathrm{Cd}$, bovine hemoglobin (Sigma) $\left(0.1 \mathrm{~mL}\right.$ of $5 \%$ solution in $\mathrm{H}_{2} \mathrm{O}$ ) was added and the sample heated for $1.5 \mathrm{~min}$ at $95^{\circ} \mathrm{C}$, cooled, and centrifuged for $5 \mathrm{~min}$ at $10,000 \times \mathrm{g}$. Addition of hemoglobin, heating, and sample centrifugation was repeated twice. Cd bound to MT in the resulting clear supernatant was determined by electrothermal AAS. MT content was expressed in micrograms of the protein per gram of wet tissue assuming that $1 \mathrm{~mol}$ of MT (6600) binds 7 moles of Cd.

\section{GSH Assay}

Total GSH (reduced + oxidized) was measured in the postmitochondrial fraction according to the method of (Tietze 1969) by using NWLSS Glutathione Assay Kit (Vancouver, WA). Briefly, an aliquot of the supernatant $(50 \mu \mathrm{L})$ was deproteinized by adding $100 \mu \mathrm{L}$ of an aqueous solution of $5 \%$ metaphosphoric acid. After centrifugation, an aliquot $(25 \mu \mathrm{L})$ of the supernatant was diluted by adding $500 \mu \mathrm{L}$ of assay buffer. To $400 \mu \mathrm{L}$ of this solution, $400 \mu \mathrm{L}$ of assay buffer, $50 \mu \mathrm{L}$ of 5,5'-dithiobis-2-nitrobenzoic acid (DTNB), and $50 \mu \mathrm{L}$ of GSH reductase in assay buffer were added and incubated for $2 \mathrm{~min} 30 \mathrm{~s}$ at room temperature. Subsequently $50 \mu \mathrm{L}$ of NADPH solution was added and the reduction rate of DTNB into 5-thio-2-nitrobenzoic acid (TNB) measured spectrophotometrically at $412 \mathrm{~nm}$ for $3 \mathrm{~min}$. GSH was expressed as $\mu \mathrm{mol} / \mathrm{g}$ wet weight.
Lipid Peroxidation Assay

Lipid peroxidation was assessed by measuring malondialdehyde formation using the thiobarbituric acid (TBA) assay (Ohkawa et al. 1979). To $0.1 \mathrm{~mL}$ of the tissue homogenate, $0.2 \mathrm{~mL}$ of $8.1 \%$ sodium dodecyl sulfate, $1.5 \mathrm{~mL}$ of $20 \%$ acetic acid, $1.5 \mathrm{~mL}$ of $0.8 \% \mathrm{TBA}$, and $0.6 \mathrm{~mL}$ of distilled water were added and vortexed. The reaction mixture was placed in a water bath at $95{ }^{\circ} \mathrm{C}$ for $1 \mathrm{~h}$. After cooling, $1.0 \mathrm{~mL}$ of distilled water and $5.0 \mathrm{~mL}$ of butanol/pyridine mixture $(15: 1 \mathrm{v} / \mathrm{v})$ were added and vortexed. After centrifugation, absorbance of the organic phase was determined at $532 \mathrm{~nm}$. Tetraethoxypropane was used to prepare a calibration curve. The results were expressed as TBA-reacting substances (TBARS) (nmol/g wet weight).

\section{Statistical Analysis}

Data are expressed as mean \pm SD. Differences between the groups and subgroups were analyzed by one-way analysis of variance (ANOVA) followed by Duncan's multiple range test (IBM SPSS Statistics 21, IBM Corporation, Somers, NY, USA). Differences at $P<0.05$ were considered statistically significant.

\section{Results}

Although enlarged liver and kidney are indicative of chronic Cd toxicity (Liu et al. 1998; Habeebu et al. 2000), in the present study subchronic dietary $\mathrm{Cd}$ (30 and $60 \mu \mathrm{g} \mathrm{Cd} / \mathrm{g}$ ) did not affect liver and kidney weights in wild and laboratorybred bank voles (Table 1). In addition, no changes of hemoglobin and hematocrit values were observed on $\mathrm{Cd}$ exposure in the two groups of bank voles. Similarly, dietary $\mathrm{Cd}$ had no effect on body mass (Table 1), and food intake $(0.16-0.18 \mathrm{~g} / \mathrm{g}$ body weight/d) in these animals.

The histopathological changes in the liver and kidneys are shown in Figures 1 and 2, respectively. Liver and kidney of control wild and laboratory-bred bank voles showed normal morphology (Figs. 1a and 2a). Normal morphology was also found in all laboratory-bred bank voles exposed to dietary $\mathrm{Cd}$ (Table 1). In contrast, focal hepatocyte swelling, vacuolation, and inflammation (leukocyte infiltration) (Fig. 1b) in liver-as well as focal proximal tubule degeneration, including epithelial cell swelling (Fig. 2b), in kidney-of all wild bank voles fed a diet containing $60 \mu \mathrm{g} \mathrm{Cd} / \mathrm{g}$ was observed (Table 1).

Liver and kidney were also analyzed for $\mathrm{Cd}, \mathrm{MT}, \mathrm{Zn}$, $\mathrm{Cu}, \mathrm{Fe}, \mathrm{TBARS}$, and GSH contents (Tables 2 and 3). Accumulation of $\mathrm{Cd}$ in liver and kidney was dose-dependent $(P<0.0001)$ and reached similar levels $(P>0.1)$ in wild and laboratory-bred bank voles. In general, hepatic 
Table 1 Body and organ weights, hematological values, and incidence of histopathological changes in liver and kidney of male wild and laboratory-bred bank voles exposed to dietary $\mathrm{Cd}$

\begin{tabular}{|c|c|c|c|c|c|c|c|}
\hline \multirow[t]{2}{*}{ Group } & \multirow[t]{2}{*}{ Final body mass (g) } & \multirow[t]{2}{*}{ Liver mass $(\mathrm{g})$} & \multirow[t]{2}{*}{ Kidney mass (g) } & \multirow[t]{2}{*}{ Hemoglobin $(\mathrm{g} / 100 \mathrm{~mL})$} & \multirow[t]{2}{*}{ Hematocrit $(\%)$} & \multicolumn{2}{|c|}{ Histopathology } \\
\hline & & & & & & Liver & Kidney \\
\hline \multicolumn{8}{|c|}{ Wild bank voles } \\
\hline Control & $15.5 \pm 1.4$ & $0.69 \pm 0.08$ & $0.17 \pm 0.02$ & $16.8 \pm 1.3$ & $48.0 \pm 1.5$ & $(-)$ & $(-)$ \\
\hline $\mathrm{Cd}-30$ & $15.0 \pm 1.5$ & $0.68 \pm 0.09$ & $0.16 \pm 0.02$ & $16.0 \pm 1.1$ & $47.8 \pm 2.0$ & $(-)$ & $(-)$ \\
\hline Cd-60 & $15.2 \pm 0.9$ & $0.68 \pm 0.07$ & $0.16 \pm 0.01$ & $15.5 \pm 0.9$ & $46.0 \pm 0.9$ & $(+)$ & $(+)$ \\
\hline \multicolumn{8}{|c|}{ Laboratory-bred bank voles } \\
\hline Control & $15.0 \pm 0.8$ & $0.67 \pm 0.08$ & $0.16 \pm 0.02$ & $16.7 \pm 1.3$ & $48.3 \pm 1.5$ & $(-)$ & $(-)$ \\
\hline $\mathrm{Cd}-30$ & $15.2 \pm 1.1$ & $0.68 \pm 0.09$ & $0.17 \pm 0.02$ & $15.9 \pm 1.1$ & $47.9 \pm 2.0$ & $(-)$ & $(-)$ \\
\hline Cd-60 & $15.3 \pm 1.1$ & $0.68 \pm 0.08$ & $0.17 \pm 0.02$ & $16.0 \pm 1.2$ & $47.0 \pm 1.6$ & $(-)$ & $(-)$ \\
\hline
\end{tabular}

Values represent mean $\pm \mathrm{SD}$ for $n=6$. Bank voles received, for 4 weeks, control diet or diets containing 30 and $60 \mu \mathrm{g} \mathrm{Cd} / \mathrm{g}$. There were no statistically significant differences between the groups and subgroups. Histopathology: normal morphology $(-)$, histopathological changes $(+)$

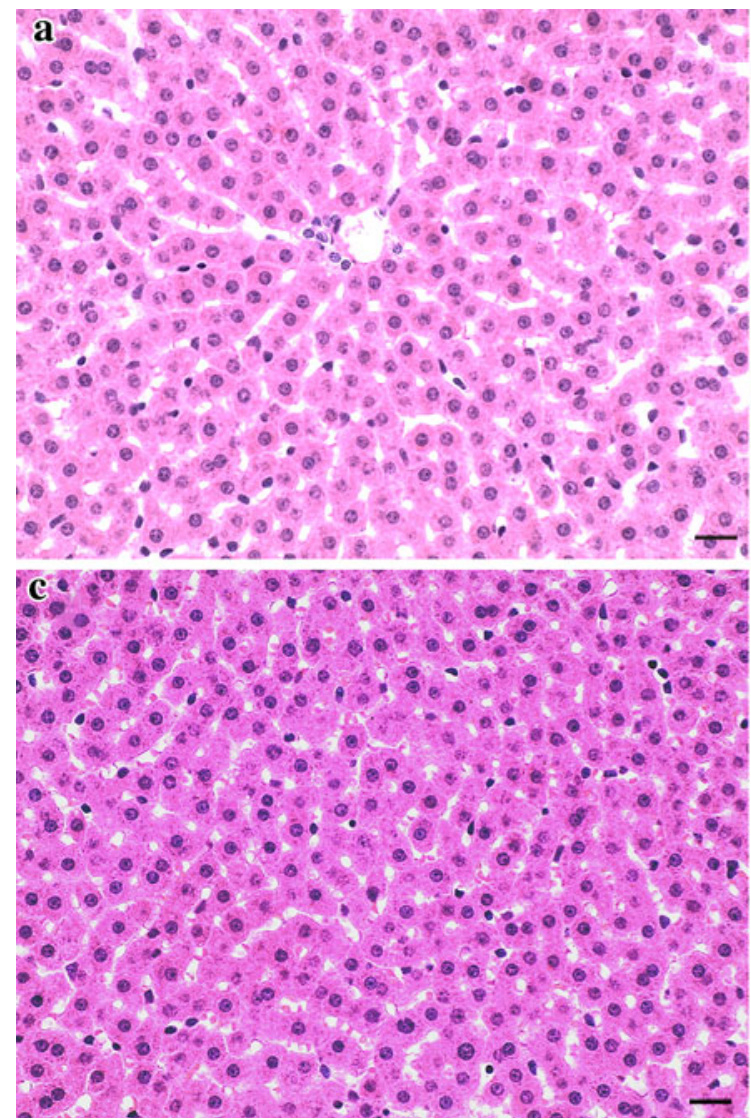

Fig. 1 Representative photomicrographs of liver section from a control wild bank voles, $\mathbf{b}$ wild bank voles exposed to dietary $\mathrm{Cd}$ in quantity of $60 \mu \mathrm{g} / \mathrm{g}$ (hepatocyte swelling [arrows], leukocyte

and renal MT levels followed a pattern similar to that of $\mathrm{Cd}$ accumulation: MT induction by $\mathrm{Cd}$ in laboratory-bred voles was not significantly greater $(P>0.1)$ than that in liver and kidney of wild animals. Subchronic consumption of Cd significantly increased $(P<0.01) \mathrm{Zn}$ concentrations in liver and kidney to similar levels in wild and laboratory-

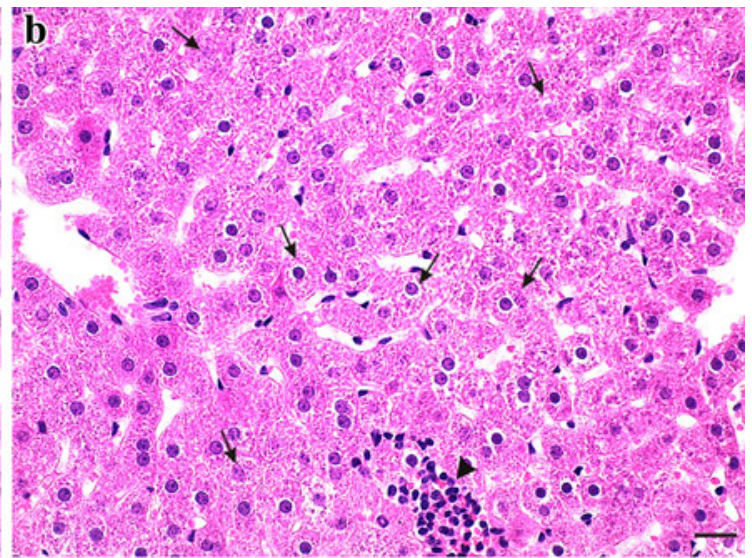

infiltration [arrowhead]), and c laboratory-bred bank voles exposed to dietary $\mathrm{Cd}$ in quantity of $60 \mu \mathrm{g} / \mathrm{g}$ (no damage is seen). Scale bar $20 \mu \mathrm{m}$

bred bank voles, but hepatic and renal $\mathrm{Cu}$ was not affected by dietary $\mathrm{Cd}$ in the two groups of animals. In contrast, dietary $\mathrm{Cd}$ decreased (in a dose-dependent fashion) hepatic Fe in wild and laboratory-bred voles; however, decreased Fe was most pronounced in wild rodents exposed to dietary $\mathrm{Cd}$ at $60 \mu \mathrm{g} / \mathrm{g}$. Renal Fe was not influenced by dietary $\mathrm{Cd}$ 


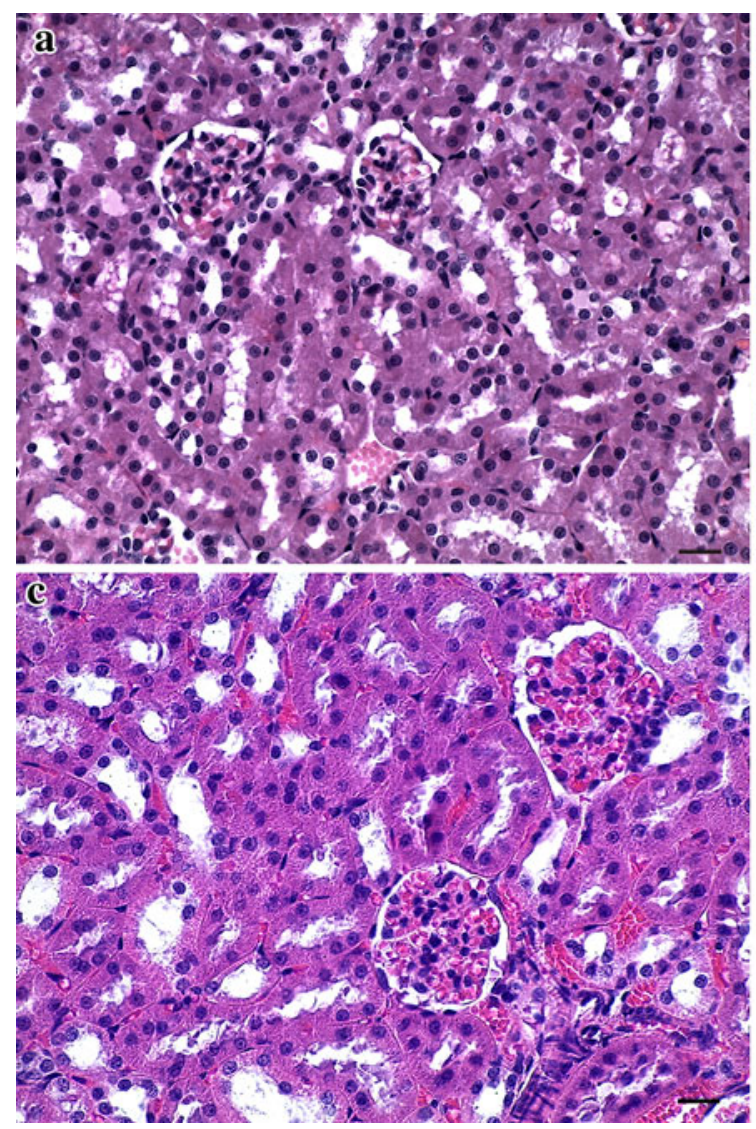

Fig. 2 Representative photomicrographs of kidney section from a control wild bank voles, b wild bank voles exposed to dietary $\mathrm{Cd}$ in quantity of $60 \mu \mathrm{g} / \mathrm{g}$ (proximal tubule degeneration [asterisk],

$(P>0.1)$ in all animals studied. Notably, lipid peroxidation, measured as TBARS in liver of wild bank voles fed a diet containing $60 \mu \mathrm{g} \mathrm{Cd} / \mathrm{g}$, decreased to $33 \%$ of that observed in control animals. No changes of this process on $\mathrm{Cd}$ exposure were found in liver of laboratory-bred voles as well as kidney of rodents from the two groups. As listed in Table 2, dietary Cd did not significantly affect $(P>0.1)$ GSH concentrations in liver of wild and laboratory-bred bank voles. Renal GSH could not be detected by the method used in this study.

\section{Discussion}

The results of the present study demonstrate dramatic differences in the development of Cd-induced liver and kidney injury between wild and laboratory-bred bank voles. $\mathrm{Cd}$ induced histopathological changes in liver and kidney only in wild animals despite the fact that tissue $\mathrm{Cd}$ accumulation was similar in the two groups of animals. These data indicate the following: (1) wild bank voles are more sensitive to $\mathrm{Cd}$ toxicity than those bred and raised under

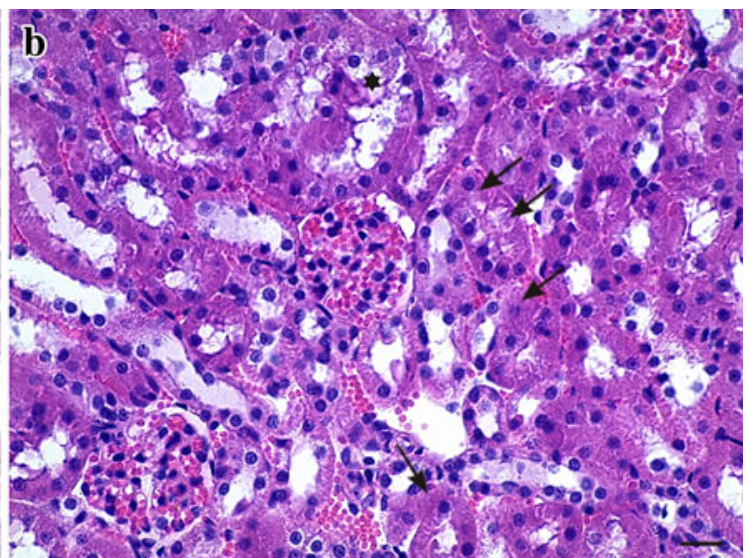

epithelial cell swelling [arrows]), and c laboratory-bred bank voles exposed to dietary $\mathrm{Cd}$ in quantity of $60 \mu \mathrm{g} / \mathrm{g}$ (no damage is seen). Scale bar $20 \mu \mathrm{m}$

laboratory conditions; and (2) the difference in sensitivity is not related to total $\mathrm{Cd}$ accumulation.

The difference in susceptibility to Cd-induced liver and kidney injury between the two groups of bank voles could be related, however, to MT induction, GSH content, oxidative stress, and $\mathrm{Zn}, \mathrm{Cu}$, and $\mathrm{Fe}$ concentrations, which are considered to be critical factors during the development of Cd toxicity (Chan and Cherian 1992; Jacquillet et al. 2006; Jihen et al. 2008; Klaassen et al. 2009; Liu et al. 2009; Whittaker et al. 2011). Indeed, it has been shown that the difference in the susceptibility of rat strains to Cd-induced liver injury relates to the induction of MT (Kuester et al. 2002; Sabolić et al. 2010; Theocharis et al. 1994); still, other investigators have not demonstrated such a relation in mouse strains (Kershaw and Klaassen 1991). The present study showed that laboratory-bred bank voles treated with $\mathrm{Cd}$ produced nonsignificantly greater amounts of hepatic and renal MT than wild voles exhibiting histopathology. Furthermore, assuming that one mol of MT (6600) binds 7 moles of $\mathrm{Cd}$, the Cd-binding capacity of hepatic and renal MT in wild animals was sufficiently high to potentially bind all Cd accumulated. Thus, MT does not appear to be 
Table 2 MT, GSH and metal concentrations, and TBARS in liver of male wild and laboratory-bred bank voles exposed to dietary Cd

\begin{tabular}{|c|c|c|c|c|c|c|c|}
\hline Group & $\begin{array}{l}\mathrm{Cd}(\mu \mathrm{g} / \mathrm{g} \text { wet } \\
\text { weight })\end{array}$ & $\begin{array}{l}\text { MT }(\mu \mathrm{g} / \mathrm{g} \text { wet } \\
\text { weight })\end{array}$ & $\begin{array}{l}\mathrm{Zn}(\mu \mathrm{g} / \mathrm{g} \text { wet } \\
\text { weight })\end{array}$ & $\begin{array}{l}\mathrm{Cu}(\mu \mathrm{g} / \mathrm{g} \text { wet } \\
\text { weight })\end{array}$ & $\begin{array}{l}\mathrm{Fe}(\mu \mathrm{g} / \mathrm{g} \text { wet } \\
\text { weight })\end{array}$ & $\begin{array}{l}\text { TBARS (nmol/g wet } \\
\text { weight) }\end{array}$ & $\begin{array}{l}\text { GSH }(\mu \mathrm{mol} / \mathrm{g} \text { wet } \\
\text { weight })\end{array}$ \\
\hline \multicolumn{8}{|c|}{ Wild bank voles } \\
\hline Control & $0.14 \pm 0.04^{\mathrm{a}}$ & $4.95 \pm 1.20^{\mathrm{a}}$ & $23.0 \pm 3.0^{\mathrm{a}}$ & $3.5 \pm 0.3^{\mathrm{a}}$ & $260 \pm 47^{\mathrm{a}}$ & $113 \pm 27^{\mathrm{a}}$ & $6.6 \pm 1.9^{\mathrm{a}}$ \\
\hline Cd-30 & $5.92 \pm 0.95^{\mathrm{b}}$ & $50.5 \pm 7.9^{\mathrm{b}}$ & $25.4 \pm 2.5^{\mathrm{ab}}$ & $3.4 \pm 0.3^{\mathrm{a}}$ & $150 \pm 40^{\mathrm{b}}$ & $100 \pm 15^{\mathrm{a}}$ & $7.2 \pm 2.1^{\mathrm{a}}$ \\
\hline Cd-60 & $11.35 \pm 1.81^{\mathrm{c}}$ & $95.0 \pm 13.0^{\mathrm{c}}$ & $27.5 \pm 3.5^{\mathrm{b}}$ & $3.7 \pm 0.4^{\mathrm{a}}$ & $70 \pm 20^{\mathrm{c}}$ & $37 \pm 10^{\mathrm{b}}$ & $6.7 \pm 2.5^{\mathrm{a}}$ \\
\hline \multicolumn{8}{|c|}{ Laboratory-bred bank voles } \\
\hline Control & $0.13 \pm 0.02^{\mathrm{a}}$ & $5.87 \pm 1.25^{\mathrm{a}}$ & $23.5 \pm 3.2^{\mathrm{a}}$ & $3.9 \pm 0.5^{\mathrm{a}}$ & $350 \pm 85^{\mathrm{a}}$ & $108 \pm 30^{\mathrm{a}}$ & $6.9 \pm 3.0^{\mathrm{a}}$ \\
\hline Cd-30 & $5.84 \pm 0.82^{\mathrm{b}}$ & $62.0 \pm 8.2^{\mathrm{b}}$ & $25.8 \pm 4.2^{\mathrm{ab}}$ & $3.8 \pm 0.4^{\mathrm{a}}$ & $210 \pm 47^{\mathrm{b}}$ & $110 \pm 15^{\mathrm{a}}$ & $6.5 \pm 2.1^{\mathrm{a}}$ \\
\hline Cd-60 & $12.50 \pm 1.65^{\mathrm{c}}$ & $107 \pm 20.0^{\mathrm{c}}$ & $28.0 \pm 3.6^{\mathrm{b}}$ & $3.8 \pm 0.6^{\mathrm{a}}$ & $140 \pm 20^{\mathrm{b}}$ & $95 \pm 20^{\mathrm{a}}$ & $7.0 \pm 2.2^{\mathrm{a}}$ \\
\hline
\end{tabular}

Values represent mean $\pm \mathrm{SD}$ for $n=6$. Bank voles received, for 4 weeks, control diet or diets containing 30 and $60 \mu \mathrm{g} \mathrm{Cd} / \mathrm{g}$. Means in the same column marked with a different superscript lower-case letter are significantly different $(P<0.05)$ (ANOVA and Duncan's multiple range test)

Table 3 MT, metal concentrations, and TBARS in kidney of male wild and laboratory-bred bank voles exposed to dietary Cd

\begin{tabular}{|c|c|c|c|c|c|c|}
\hline Group & $\begin{array}{l}\text { Cd }(\mu \mathrm{g} / \mathrm{g} \text { wet } \\
\text { weight) }\end{array}$ & $\begin{array}{l}\text { MT ( } \mu \mathrm{g} / \mathrm{g} \text { wet } \\
\text { weight) }\end{array}$ & $\begin{array}{l}\mathrm{Zn}(\mu \mathrm{g} / \mathrm{g} \text { wet } \\
\text { weight })\end{array}$ & $\begin{array}{l}\mathrm{Cu}(\mu \mathrm{g} / \mathrm{g} \text { wet } \\
\text { weight })\end{array}$ & $\begin{array}{l}\mathrm{Fe}(\mu \mathrm{g} / \mathrm{g} \text { wet } \\
\text { weight })\end{array}$ & $\begin{array}{l}\text { TBARS (nmol/g wet } \\
\text { weight) }\end{array}$ \\
\hline \multicolumn{7}{|c|}{ Wild bank voles } \\
\hline Control & $0.75 \pm 0.20^{\mathrm{a}}$ & $19.7 \pm 4.6^{\mathrm{a}}$ & $15.4 \pm 2.2^{\mathrm{a}}$ & $5.7 \pm 0.9^{\mathrm{a}}$ & $105 \pm 20^{\mathrm{a}}$ & $155 \pm 30^{\mathrm{a}}$ \\
\hline Cd-30 & $9.6 \pm 1.3^{b}$ & $80 \pm 11^{\mathrm{b}}$ & $17.5 \pm 3.0^{\mathrm{ab}}$ & $5.5 \pm 1.0^{\mathrm{a}}$ & $110 \pm 15^{\mathrm{a}}$ & $157 \pm 25^{\mathrm{a}}$ \\
\hline Cd-60 & $18.0 \pm 2.0^{\mathrm{c}}$ & $150 \pm 21^{\mathrm{c}}$ & $22.2 \pm 3.3^{\mathrm{b}}$ & $5.6 \pm 0.7^{\mathrm{a}}$ & $104 \pm 28^{\mathrm{a}}$ & $148 \pm 35^{\mathrm{a}}$ \\
\hline \multicolumn{7}{|c|}{ Laboratory-bred bank voles } \\
\hline Control & $0.36 \pm 0.15^{\mathrm{a}}$ & $20.1 \pm 4.2^{\mathrm{a}}$ & $15.6 \pm 2.0^{\mathrm{a}}$ & $5.1 \pm 0.5^{\mathrm{a}}$ & $102 \pm 21^{\mathrm{a}}$ & $142 \pm 18^{\mathrm{a}}$ \\
\hline Cd-30 & $10.0 \pm 1.5^{\mathrm{b}}$ & $95 \pm 13^{\mathrm{b}}$ & $18.5 \pm 3.0^{\mathrm{ab}}$ & $5.6 \pm 0.8^{\mathrm{a}}$ & $105 \pm 18^{\mathrm{a}}$ & $150 \pm 15^{\mathrm{a}}$ \\
\hline Cd-60 & $18.5 \pm 3.7^{\mathrm{c}}$ & $171 \pm 20^{\mathrm{c}}$ & $23.0 \pm 3.4^{\mathrm{b}}$ & $5.4 \pm 0.6^{\mathrm{a}}$ & $95 \pm 15^{\mathrm{a}}$ & $148 \pm 20^{\mathrm{a}}$ \\
\hline
\end{tabular}

Values represent mean $\pm \mathrm{SD}$ for $n=6$. Bank voles received, for 4 weeks, control diet or diets containing 30 and $60 \mu \mathrm{g} \mathrm{Cd} / \mathrm{g}$. Means in the same column marked with a different superscript lower-case letter are significantly different $(P<0.05)$ (ANOVA and Duncan's multiple range test)

the major factor responsible for the difference observed between the wild and laboratory-bred bank voles. Likewise, GSH, which is known to provide protection against Cd toxicity (Chan and Cherian 1992), could have had only a negligible effect because its content was relatively stable in all bank voles exposed to $\mathrm{Cd}$ (Table 2). Moreover, hepatic and renal $\mathrm{Zn}$, which are also known to protect against Cd toxicity (Jacquillet et al. 2006; Jihen et al. 2008), increased to the same level in the two groups (Tables 2 and 3). This suggests that the fraction of $\mathrm{Zn}$, which most likely was sequestered by MT, was ineffective in protecting against toxicity. It also seems unlikely that liver and kidney injury from $\mathrm{Cd}$ exposure in wild bank voles was due to increased oxidative stress (thought to be a cellular mechanism of toxicity [Thévenod and Friedmann 1999; Liu et al. 2009; Wang et al. 2010]) because hepatic and renal lipid peroxidation-as well as concentrations of pro-oxidant elements, such as $\mathrm{Fe}$ and $\mathrm{Cu}$ (Whittaker et al. 2011) - were similar or even lower than those in the laboratory-bred animals. Therefore, another mechanism is probably involved in Cd-induced liver and kidney injury in wild bank voles.

Numerous studies have shown that $\mathrm{Cd}$ decreases intestinal $\mathrm{Fe}$ absorption and its concentration in the liver of various animals, including the bank vole (Groten et al. 1991; Włostowski et al. 2000, 2003; Świergosz-Kowalewska and Holewa 2007). In the present study, dietary Cd brought about, in a dose-dependent pattern, an Fe decrease in liver of wild and laboratory-bred bank voles; however, the decrease in wild bank voles appeared to be more pronounced than that in the laboratory-bred animals (Table 2). Because $\mathrm{Fe}$ is an essential component of the Fenton reaction (hydroxyl radical production) as well as of several proteins and enzymes composing the mitochondrial respiratory chain, one would expect major changes to occur concurrently in the related oxidative processes, such as lipid peroxidation. Indeed, a dramatic decrease in lipid peroxidation in the liver of wild voles exhibiting the lowest $\mathrm{Fe}$ concentration (Table 2) suggests that this may be the case. Furthermore, the considerable decrease in hepatic $\mathrm{Fe}$ 
could lead to some disturbances in the mitochondrial respiration and ATP synthesis. If so, ATP deprivation could cause the loss of ionic control and cellular disintegration: The presence of hepatocyte swelling (Fig. 1b) in wild bank voles exposed to the highest dose of dietary $\mathrm{Cd}$ might support this assumption. In contrast to liver, kidney injury in wild bank voles was not accompanied by a decrease in $\mathrm{Fe}$ and lipid peroxidation (Table 3). This remains in some contrast to a previous study that showed a decrease in renal $\mathrm{Fe}$ and lipid peroxidation on $\mathrm{Cd}$ exposure (Włostowski et al. 2000); however, the discrepancy may be due to a different dietary $\mathrm{Cd}$ concentration and exposure time used in the two studies. Still, the occurrence of swollen proximal tubule epithelial cells (Fig. 2b) may also indicate dysfunction of mitochondrial respiration. This could be related to a Cd-MT complex released by the injured hepatocytes into the blood and taken up by the proximal tubule cells; notably, the complex has been shown to adversely affect mitochondrial respiration in these cells (Tang and Shaikh 2001). These data confirm the notion that dietary Cd may produce histopathological changes in liver and kidney indirectly through decreasing the hepatic $\mathrm{Fe}$ and $\mathrm{Fe}$ dependent oxidative processes (Włostowski et al. 2000, 2003).

Although a significant decrease of hepatic Fe caused by dietary $\mathrm{Cd}$ in wild bank voles appears to be an important factor responsible for liver and kidney injury, the reason for the difference in the extent of decreased hepatic $\mathrm{Fe}$ in response to $\mathrm{Cd}$ exposure between wild and laboratory-bred bank voles remains unknown. It cannot be ruled out that the difference may be related to the fact that free-ranging bank voles, compared with those bred and raised in the laboratory, are subjected to various stressful conditions, including changes in food resources and ambient temperature, threats from predators, and interaction with conspecifics, which can elicit psychological stress in these animals (Marchlewska-Koj et al. 2003; Tidhar et al. 2007). Importantly, this stress has been shown to result in various pathophysiological processes, including impairment of $\mathrm{Fe}$ absorption, specifically the expression of ferroportin in enterocytes (Chen et al. 2009). Whether or not stress is responsible for the significant decrease of hepatic $\mathrm{Fe}$ on $\mathrm{Cd}$ exposure in wild bank voles remains to be elucidated in future studies.

In conclusion, these data indicate that free-ranging bank voles are more susceptible to $\mathrm{Cd}$-induced liver and kidney injury than those bred and raised under laboratory conditions. The difference in sensitivity appears not to be related to Cd disposition, MT induction, GSH content, oxidative stress, or $\mathrm{Zn}$ concentration; however, it may be associated with a distinct decrease of hepatic $\mathrm{Fe}$ in response to $\mathrm{Cd}$ exposure between wild and laboratory-bred bank voles.
Conflict of interest The authors declare that they have no conflict of interest.

Open Access This article is distributed under the terms of the Creative Commons Attribution License which permits any use, distribution, and reproduction in any medium, provided the original author(s) and the source are credited.

\section{References}

Beiglböck C, Steineck T, Tataruch F, Ruf T (2002) Environmental cadmium induces histopathological changes in kidneys of roe deer. Environ Toxicol Chem 21:1811-1816

Chan HM, Cherian MG (1992) Protective roles of metallothionein and glutathione in hepatotoxicity of cadmium. Toxicology 72:281-290

Chen J, Shen H, Chen C, Wang W, Yu S, Zhao M et al (2009) The effect of psychological stress on iron absorption in rats. BMC Gastroenterol 9:83

Damek-Poprawa M, Sawicka-Kapusta K (2004) Histopathological changes in the liver, kidney and testes of bank voles environmentally exposed to heavy metal emission from the steelworks and zinc smelter in Poland. Environ Res 96:72-78

Goyer RA, Miller CR, Zhu SY, Victery W (1989) Non-metallothionein-bound cadmium in the pathogenesis of cadmium nephrotoxicity in the rat. Toxicol Appl Pharmacol 101:232-244

Groten JP, Sinkeldam EJ, Muys T, Luten JB, van Bladeren PJ (1991) Interaction of dietary $\mathrm{Ca}, \mathrm{P}, \mathrm{Mg}, \mathrm{Mn}, \mathrm{Cu}, \mathrm{Fe}, \mathrm{Zn}$ and $\mathrm{Se}$ with the accumulation and oral toxicity of cadmium in rats. Food Chem Toxicol 29:249-258

Groten JP, Koeman JH, van-Nesselrooij JH, Luten JB, Fentener-van Vlissingen JM, et al. (1994) Comparison of renal toxicity after long-term oral administration of cadmium chloride and cadmiummetallothionein in rats. Fundam Appl Toxicol 23:544-552

Habeebu SM, Liu J, Liu Y, Klaassen CD (2000) Metallothionein-null mice are more sensitive than wild-type mice to liver injury induced by repeated exposure to cadmium. Toxicol Sci 55:223-232

Jacquillet G, Barbier O, Cougnon M, Tanc M, Namorado MC, Martin $D$ et al (2006) Zinc protects renal function during cadmium intoxication in the rat. Am J Physiol Renal Physiol 290:F127F137

Jihen EH, Imed M, Fatima H, Kerkeni A (2008) Protective effects of selenium (Se) and zinc $(\mathrm{Zn})$ on cadmium $(\mathrm{Cd})$ toxicity in the liver and kidney of the rat: histology and $\mathrm{Cd}$ accumulation. Food Chem Toxicol 46:3522-3527

Kershaw WC, Klaassen CD (1991) Cadmium-induced elevation of hepatic isometallothionein concentrations in inbred strains of mice. Chem Biol Interact 78:269-282

Klaassen CD, Liu J, Diwan BA (2009) Metallothionein protection of cadmium toxicity. Toxicol Appl Pharmacol 238:215-220

Kuester RK, Waalkes MP, Goering PL, Fisher BL, McCuskey RS, Sipes IG (2002) Differential hepatotoxicity induced by cadmium in Fischer 344 and Sprague-Dawley rats. Toxicol Sci 65:151-159

Lehman LD, Klaassen CD (1986) Dosage-dependent disposition of cadmium administered orally to rats. Toxicol Appl Pharmacol 84:159-167

Liu ZP (2003) Lead poisoning combined with cadmium in sheep and horses in the vicinity of non-ferrous metal smelters. Sci Total Environ 309:117-126 
Liu J, Kershaw WC, Liu Y, Klaassen CD (1992) Cadmium-induced hepatic endothelial cell injury in inbred strains of mice. Toxicology 75:51-62

Liu J, Habeebu SS, Liu Y, Klaassen CD (1998) Acute CdMT injection is not a good model to study chronic Cd nephropathy: comparison of chronic $\mathrm{CdCl}_{2}$ and CdMT exposure with acute CdMT injection in rats. Toxicol Appl Pharmacol 153:48-58

Liu J, Qu W, Kadiiska MB (2009) Role of oxidative stress in cadmium toxicity and carcinogenesis. Toxicol Appl Pharmacol 238:209-214

Marchlewska-Koj A, Kapusta J, Kruczek M (2003) Prenatal stress modifies behavior in offspring of bank voles (Clethrionomys glareolus). Physiol Behav 79:671-678

Ohkawa H, Ohishi N, Yagi K (1979) Assay of lipid peroxides in animal tissues by thiobarbituric acid reaction. Anal Biochem 95:351-358

Sabolić I, Breljak D, Škarica M, Herak-Kramberger CM (2010) Role of metallothionein in cadmium traffic and toxicity in kidneys and other mammalian organs. Biometals 23:897-926

Salińska A, Włostowski T, Zambrzycka E (2012) Effect of dietary cadmium and/or lead on histopathological changes in the kidneys and liver of bank voles Myodes glareolus kept in different group densities. Ecotoxicology 21:2235-2243

Sanchez-Chardi A, Penarroja-Matutano C, Borras M, Nadal J (2009) Bioaccumulation of metals and effects of a landfill in small mammals Part III: structural alterations. Environ Res 109:960-967

Satarug S, Baker JR, Urbenjapol S, Haswell-Elkins M, Reilly PEB, Williams DJ et al (2003) A global perspective on cadmium pollution and toxicity in non-occupationally exposed population. Toxicol Lett 137:65-83

Świergosz-Kowalewska R, Holewa I (2007) Cadmium, zinc and iron interactions in the tissues of bank vole Clethrionomys glareolus after exposure to low and high doses of cadmium chloride. Biometals 20:743-749

Tang W, Shaikh ZA (2001) Renal cortical mitochondrial dysfunction upon cadmium-metallothionein administration to Sprague-Dawley rats. J Toxicol Environ Health A 62:221-235

Theocharis SE, Margeli AP, Giannakou N, Drakopoulos DS, Mykoniatis MG (1994) Cadmium-induced hepatotoxicity in three different rat strains. Toxicol Lett 70:39-48
Thévenod F (2009) Cadmium and cellular signaling cascades: to be or not to be? Toxicol Appl Pharmacol 238:221-239

Thévenod F, Friedmann JM (1999) Cadmium-mediated oxidative stress in kidney proximal tubule cell induced degradation of $\mathrm{Na}^{+} / \mathrm{K}^{+}$-ATP-ase through proteosomal and endo-lysosomal proteolytic pathways. FASEB J 13:1751-1761

Tidhar WL, Bonier F, Speakman JR (2007) Sex- and concentrationdependent effects of predator feces on seasonal regulation of body mass in the bank vole Clethrionomys glareolus. Horm Behav 52:436-444

Tietze F (1969) Enzymatic method for the quantitative determination of nanogram amounts of total and oxidized glutathione: application to mammalian blood and other tissues. Anal Biochem 27:502-522

Wang L, Li J, Li J, Liu Z (2010) Effects of lead and/or cadmium on the oxidative damage of rat kidney cortex mitochondria. Biol Trace Elem Res 137:69-78

Whittaker MH, Wang G, Chen XQ, Lipsky M, Smith D, Gwiazda R et al (2011) Exposure to $\mathrm{Pb}, \mathrm{Cd}$, and As mixtures potentiates the production of oxidative stress precursors: 30 day, 90 day, and 180 day drinking water studies in rats. Toxicol Appl Pharmacol 254:154-166

Włostowski T, Krasowska A, Łaszkiewicz-Tiszczenko B (2000) Dietary cadmium induces histopathological changes despite a sufficient metallothionein level in the liver and kidneys of the bank vole (Clethrionomys glareolus). Comp Biochem Physiol C Toxicol Pharmacol 126:21-28

Włostowski T, Krasowska A, Bonda E (2003) An iron-rich diet protects the liver and kidneys against cadmium-induced injury in the bank vole (Clethrionomys glareolus). Ecotoxicol Environ Saf 54:194-198

Włostowski T, Bonda E, Krasowska A (2004) Photoperiod affects hepatic and renal cadmium accumulation, metallothionein induction, and cadmium toxicity in the wild bank vole (Clethrionomys glareolus). Ecotoxicol Environ Saf 58:29-36

Włostowski T, Dmowski K, Bonda-Ostaszewska E (2010) Cadmium accumulation, metallothionein and glutathione levels, and histopathological changes in the kidneys and liver of magpie (Pica pica) from a zinc smelter area. Ecotoxicology 19:1066-1073 